\title{
Observations on the Development and Structure of the Adrenal Medulla in the Guinea Pig
}

\author{
Takashi Ito \\ Department of Anatomy, Nagoya University School of Medicine, Nagoya \\ (Director: Prof. Ch. Togari)
}

\begin{abstract}
A large number of studies have been made on the development of the adrenal medulla in many mammalian species including man (Wiesel, in the pig, 1901, and in man, 1902: Whitehead, in the pig, 1903; Jackson, in the rat, 1919; Bloch, in the guinea pig, 1921; Weymann, in the pig, 1922; Hett, in man, 1925; Kohno, in man and some animals, 1925; Bessho, in the mouse, 1927a, and in the rat, 1927b; Keene and Hewer, in man, 1927; Harman and Derbyshire, in the guinea pig, 1932; Kudo and Kakiyama, in the bat, 1950a, rabbit, 1950b, and mouse, 1950c). In the guinea pig, although a few reports on this subject have been published, there are still some gaps, particularly in our knowledge of the differentiation of the medullary cells throughout pre- and postnatal life. Furthermore, concerning the minute structure of the medulla, there is as yet insufficient information about this animal, in spite of considerable works on various other species. Therefore this paper presents the results of a study of these problems in the guinea pig which is one of the most common labora. tory animals. It is hoped that the information acquired from this study may provide a more precise morphological bacikground for other future works on the adrenal medulla of this animal.
\end{abstract}

\section{Material and Methods}

Animals used in this study were a closely graded of 29 guinea pig embryos ranging in length from 2.0 to $10.0 \mathrm{~cm}$ and 71 guinea pigs of both sexes ranging in age from birth to 450 days. The adrenals were removed immediately after death or under light ether anesthesia, and then placed in fixative, except for some of the earliest embryos which 
were fixed whole without removal of the adrenals. The large glands of the postnatal animals were carefully cut into two or three pieces before fixation to insure better penetration of the fixative. The fixatives employed were Bouin's, Ciaccio's, Helly's, Orth's, Regaud's fluids, Zenker-formalin.acetic acid mixture and $10 \%$ neutral formalin. The adrenals fixed in Ciaccio's, Helly's or Regaud's fluids were post-chromed in 3\% potassium bichromate for four to seven days. The tissues were dehydrated, embedded in paraffin and then cut serially in thickness of 5-7 $\mu$. The stains chiefly employed were hematoxylin-eosin and Heidenhain's iron hematoxylin. In addition, some of the sections were stained with Heidenhain's azan stain, hematoxylin-trichrome stain (acid fuchsinorange G-anilin blue), Weigert's resorcin-fuchsin stain for elastic fibers or Bielschowsky's impregnation stain for reticular fibers.

\section{Results and Discussion \\ Development of Medulla}

\section{(A) Medullary cells and Ganglion cells.}

Among previous descriptions on the development of the adrenal medulla, there is some lack of uniformity in the nomenclature relating to the various stages in the differentiation of the medullary cells. The terms in most common usage at the present time are the ones first introduced by Poll (1906). This nomenclature was followed previously by Hett (1925) and Bessho (1927a, b), and recently also by Coupland (1952) who described the development of the human abdominal paraaortic bodies. These terms will be employed in the following description, because they are believed to be most valid and useful, as well as popular.

\section{Sympathogonia.}

In the $2 \mathrm{~cm}$ embryo, the medullary anlage is found along the dorsomedial periphery of the already forming cortical anlage, which, composed of cords of cells, can be readily distinguished from the surrounding tissue. The medullary anlage lies close to the sympathetic ganglion which is united with the sympathetic chain by the nerve bundle, and it consists of the sympathogonia. The sympathogonia (fig. 1) have small, round to oval, comparatively deeply-staining nuclei and very scanty cytoplasm. The nucleus contains several, extremely large nucleoli which appear as conspicuously basophilic spherules with chromatin coherent around them. The nucleus is characterized by the presence of such prominent nucleoli. The sympathogonia then migrate 
into the cortex as small masses. In the $3-3.3 \mathrm{~cm}$ embryos, considerable amounts of them have already invaded the cortex, and some of them begin to differentiate into the pheochromoblasts as will be later described. The sympathogonia are generally arranged in clumps, often in cords along nerve fibers, sometimes showing a rosette arrangement like a syncytium. The migration of these cells continues until about the $4.5 \mathrm{~cm}$ stage. After this stage onwards, although the adrenal often lies close to the sympathetic ganglion until the end of embryonal life, no indication can be seen of any migration of the cells from the ganglion to the adrenal. Mitotic figures are frequently seen until the $5 \mathrm{~cm}$ stage, but hereafter they gradually become reduced in number. After the $3 \mathrm{~cm}$ stage there often occurs some degeneration among the sympathogonia, as indicated by the fragmentation of the nuclei into spherical parts of different sizes. Thus the sympathogonia undergo degeneration simultaneously with multiplication (fig. 3). This is in agreement with the observations of Hett (1925) that in human embryos occasional signs of degeneration are evident in these cells. As development proceeds, the sympathogonia gradually become diminished in number through transformation into the pheochromoblasts and sympathoblasts. Thus, in the $8 \mathrm{~cm}$ embryo they are extremely rare, and after the $9 \mathrm{~cm}$ stage they are generally no longer found. The more central sympathogonia within the adrenal gland tend to differentiate earlier than the more peripheral ones. Hence, the sympathogonia, if any, generally persist nearer to the periphery of the gland.

\section{Pheochromoblasts.}

Some of the sympathogonia undergo further differentiation simultaneously with the migration into the adrenal. In the $3 \mathrm{~cm}$ embryo, considerable numbers of them are found being transformed into pheochromoblasts. These pheochromoblasts are the immature forms which were referred to as transitional forms by Bessho (1927a, b). The nuclei of these cells are somewhat larger and stained less deeply than those of the sympathogonia. The nucleoli are mostly two or three, but sometimes scarcely recognizable. Thus these nucleoli are no longer so conspicuous as those in the nuclei of the sympathogonia. The cytoplasm is a little increased in amount, and stains faintly (fig. 2). The number of pheochromoblasts becomes gradually increased through both mitotic division and transformation from the sympathogonia. Associated with the increase in number, these cells become arranged in clumps or short cords which irregularly anastomose with one another between the cortical strands. Thus, in the $4.5 \mathrm{~cm}$ embryo, they are 
the-predominant cell type of the medullary tissue which has swarmed into the center of the adrenal. At the $5 \mathrm{~cm}$ stage, there occurs further differentiation in some of these pheochromoblasts, which is characterized chiefly by the enlargement of the cytoplasm. The newly formed cells are the mature pheochromoblasts. Particularly, the pheochromoblasts facing the blood vessels tend to assume an elongated form arranged with their long diameter perpendicular to the blood spaces, looking somewhat columnar (fig. 4). During embryonal life, however, the above-mentioned immature pheochromoblasts are still present in considerable amounts particularly near the periphery of the medulla. They persist as small masses postnatally until the 20th day of age, but from this time onward they disappear in general. The pheochromoblasts of this type can be readily distinguished from the mature ones or pheochromocytes, because their smaller nuclei are generally very close together. The mature pheochromoblasts, being forms differentiating into the pheochromocytes, bear a resemblance in appearance to the latter except that the former do not yet present a chromaffin reaction. In the $6.4-7 \mathrm{~cm}$ stages, these cells are more increased in amount, but simultaneously transformation into the pheochromocytes also occurs to a considerable extent. Then in the $8-8.3 \mathrm{~cm}$ embryos, the medullary elements consist, for the greater part, of these two cell forms. From late embryonal to early postnatal life, the mature pheochromoblasts gradually decrease in number through transformation into the pheochromocytes, and the majority of them complete differentiation into the latter by the 10th postnatal day, although some persist until the age of 20 days. In more advanced life they are generally not found but rarely present. In the guinea pig, Bloch (1921) observed that the sympathogonia persist even in the adult medulla. However, I cannot substantiate this observation; the cells persisting are usually the pheochromoblasts, not the sympathogonia. Among the mature pheochromoblasts, mitotic figures are frequently seen in the earlier stages, but are considerably diminished toward the end of embryonal life. Postnatally they, though in small numbers, are seen for 16 days. 3. Pheochromocytes.

In the $6 \mathrm{~cm}$ embryo, the cytoplasm of some of the mature pheochromoblasts shows a faint yellow-brown color after fixation in Zenkerformol or Müller-formol; that is, the pheochromocytes can first be recognized at this stage. Even in the embryos of the same size, how. ever, there is individually considerable variation as to the amount of the pheochromocytes. After this period the chromaffin reaction, although 
as yet faint, is fairly constant. In the embryo of $8.5 \mathrm{~cm}$, the reaction is considerably marked with the concomitant increase in the number of the pheochromocytes. After this stage, the pheochromocytes become gradually increased in number, until at 10 days of age they constitute nearly all the parenchymal elements of the medulla. Details of these cells will be described later.

\section{Sympathoblasts and Ganglion cells.}

The medulla of the guinea pig contains ganglion cells in relatively small numbers. These cells develop from the sympathogonia after passing through the stage of sympathoblasts. The sympathoblasts first appear in small numbers in the $3-3.3 \mathrm{~cm}$ embryos. After this their number increases by transformation from the sympathogonia. The sympathoblasts tend to lie in the periphery of the medullary tissue as the sympathogonia. They are generally arranged in small irregular clumps, forming an occasional rosette, but some are scattered singly among the sympathogonia. The sympathoblasts (fig. 5) are somewhat increased in the sizes of both the nucleus and cytoplasm as compared with the sympathogonia. The nuclei are stained less deeply than those of the sympathogonia, but still bear a resemblance to those of the sympathogonia rather than to the definite cells. In the sympathoblasts mitotic division is seldom found. In between the 6.5 and $8.3 \mathrm{~cm}$ stages, on the other hand, some of these cells are seen undergoing degenerative changes as observed in the sympathogonia. As development advances, the sympathoblasts gradually acquire more cytoplasm, and their nuclei become enlarged and vesicular, until they have the characteristic appearance of ganglion cells. After this time onward transformation of the sympathoblasts into the ganglion cells gradually proceeds, and is almost completed at about the time of birth. The ganglion cells are present singly or in small groups within the medulla. They are often located near the cortico-medullary boundary, and they may rarely be found within the cortex or even just beneath the capsule of the gland.

(B) Blood vessels and Connective tissue.

In the earlier stages of development, the less differentiated cells of the medulla, such as the sympathogonia, immature pheochromoblasts and sympathoblasts, are mingled within the cortical tissue, with which they are in close contact. As development progresses, the adrenal becomes more and more vascular. Thus the developing blood vessels come to intervene between the masses of the cells of the medulla and the cortical tissue. The blood vessels are, for the most part, ordinary embryonic capillaries in the earlier stages. In late embryonal life, as 
T. Ito

the vascularity of the medulla becomes increased, the blood vessels forming the net-work become relatively wide in places to form sinuses, especially venous ones, as seen in the adult medulla. The fibrous connective tissue accompanying the blood vessels encloses the masses of the medullary cells. In late embryonal and early postnatal life, the stromal pads also become gradually developed with the concomitant development of vascularization. Simultaneously the cortical tissues within the medulla slowly decrease in amount, and demarcation between cortex and medulla gradually become sharp. Thus, the arrange. ment of the medullary cells gradually becomes well organized, until at about 8-10 days of age the medulla shows an architecture similar to that of the adult. With advancing age essential changes do not occur in architectural patterns, although the fibrous tissues appear somewhat increased in some adult animals.

\section{Structure of Medulla}

\section{(A) General features.}

The medullary cells, pheochromocytes or chromaffin cells, are arranged in irregular clumps or cords, occasionally showing an almost follicular-like arrangement. The cell masses are surrounded by a small amount of fibrous connective tissue, and are in contact with the irregularly anastomosing, sinusoidal or capillary blood spaces. The connective tissues around the cell masses are abundant in elastic and reticular fibers. Both these fibers enclose the cell masses, but do "not penetrate between individual cells. These observations regarding the elastic fibers are accordant with those of Dewitzky (1912) in several animals and Bessho $(1927 \mathrm{a}, \mathrm{b})$ in mice and rats; and those regarding the reticular fibers, with those of Kodama (1933) in several species and Lever (1952) in rats.

(B) Shape of the medullary cell.

The medullary cells, in agreement with Fuhrmann's description (1904), considerably vary in shape, from irregular polygonal to almost columnar forms (figs. 7, 8). Especially, when they are in intimate contact with the blood vessels, they tend to assume an elongated form with the long axis perpendicular to the blood spaces (fig. 7).

Regarding the shape of the medullary cells, Dewitzky (1912), Kolmer (1918), and Hirai (1933) recognized two types of these cells in some species of mammals: namely, ovoid and columnar forms. Such differentiation is said to be more conspicuous particularly in horses or cows, but not to be seen in rodents like rabbits and rats ( $\mathrm{Hirai}$, 
1933). According to the present observations, the medullary cells of the guinea pig are polymorphous as above noted. Nevertheless, in the animal under consideration at least, it seems hardly possible to classify the cells on the basis of the shape, because the shape variations are only relative and transitional in degree.

Bennett and Kilham (1940) described that in the cat the majority of the medullary cells possess a polarity with respect to the blood vessels, displaying a secretory pole toward the vein and a nutrient pole toward the capillary. Lever (1952) stated, on the contrary, that in the rat such an arrangement cannot be constantly recorded as normal. In the guinea pig, although some cells, particularly those in direct contact with the blood vessels, appear columnar with one pole toward the blood space, the other cells, rather rounded, do not possess any definite polarity. Therefore, in this animal at least there seem to be little absolute criteria for the view of Bennett and Kilham (1940).

(C) Nucleus of the medullary cell.

The nuclei of the medullary cells are round or oval and vesicular. They occupy mostly more or less eccentric positions. In particular, when the cells are columnar in shape, there is a tendency for the nuclei to be located toward the side opposite to the blood vessel on which the cells abut. The diameter of the nuclei is generally $6.5-8.5 \mu$, but much larger nuclei rarely occur. These large nuclei are generally long elliptical in shape, measuring $13-14 \mu \times 8-9 \mu$ in diameter. There are also found the nuclei of intermediate size between ones of normal size and ones of larger size.

The variations in the nuclear size of the medullary cells have been reported in man (Cla ra, 1937; En jo, 1947b). In the guinea pig, since the larger nuclei, if any, are exceedingly rare, the nuclear size appears to be fairly uniform in general. The type of division in the medullary cells has been noted to be amitosis (Fuhrmann, 1904; Kolmer, 1918; Clara, 1937; En jo, 1947b). Particularly, Clara stated that the large, elliptical nuclei become constricted and then divide into two, and therefore that the large nuclei are intimately concerned with amitosis. In the guinea pig too, many of the large nuclei, in agreement with Clara's finding, actually appear long elliptical in shape. However, any features that may suggest the possibility of amitotic division are scarcely evident in these large nuclei. Hence, at the present stage of this study, any definite indication can hardly be drawn regarding the significance of the large nuclei. Here it will suffice merely to refer to the rare occurrence of medullary cells with large nucleus in the guinea pig. 
The nucleoli contained in the nucleus of the medullary cell are variable in number; in some nuclei they are inconspicuous, while in others, they may be two or three. When two or more are present, one of them sometimes is relatively enlarged and prominent.

The nuclei of the adult medullary cells sometimes contain conspicuous intranuclear spheres (fig. 6). These spheres are literally spherical in shape, and stained homogeneously with eosin. They are much larger than the nucleoli, the average being between 2.5 and $3 \mu$ in diameter. In some few cases, the exceedingly large sphere almost fills the nucleus. On the other hand, the smallest ones are not always distinct from the nucleoli. The spheres usually occur singly within a single nucleus. They are generally located eccentrically in the nucleus, occasionally being in close attachment to the nuclear membrane.

The intranuclear spheres in the medullary cells have been observed in man by Clara (1937) and Enjo (1947b), who believed them to be derived from the nucleolus. In the guinea pig too, it seems likely that the spheres develop from the nucleoli, because there are intermediate, transitional forms between both. As regards the fate of the intranuclear spheres, En jo stated that their contents pass into the cytoplasm. According to my results, the spheres sometimes are seen in direct contact with the nuclear membrane, and in some few cases the minute incisures of the nuclear membrane are found penetrating into the interior as far as the spheres. These findings may suggest the possibility of a following discharge of the contents of the spheres; but there must be more convincing evidence before such a conclusion can be reached. In the normal guinea pigs at least, the occurrence of the spheres is not frequent enough to permit a precise determination of this problem, and it still appears to be preferable to leave this an open question.

(D) Cytoplasm of the medullary cell.

The details of the cytoplasm of the medullary cells are best seen with iron hematoxylin stain after Ciaccio's fixation, as far as I could examine. The following description is based mostly on observations on such sections (figs. 7, 8). The cytoplasm is filled with very fine granules. According to the amount of these granules, it appears very variable in appearance from cell to cell, ranging from dark to light. Among the granules there are found minute vacuoles. That the granules become enlarged and liquefy into these minute vacuoles may be said from the presence of transitions between both. Subsequently such minute vacuoles coalesce or fuse to form larger ones. The larger vacuoles, 
although individually varying in amount, are usually very frequently seen. The vacuoles vary greatly in size from very small ones to large ones of almost nuclear size or larger. The vacuoles of a smaller size are distributed sparsely throughout the cytoplasm, but the larger ones which are assumed to be formed through coalescence of the former tend to lie near the periphery of the cell, especially the side toward the blood vessel.

The granules of the medullary cells have been repeatedly discussed by several workers (Stoerk and Haberer, 1908; Hirai, 1933; Ka meda, 1936; Adachi, 1944; Enjo, 1947a). As to the granules, perhaps the view most commonly accepted is that the granules liquefy into vacuoles and then are discharged. The vacuoles also have been observed by a number of investigators besides the above-mentioned workers, and they have been regarded as representing features which are intimately related to the discharge of the hormone of the cells (Kahn, 1911, 1926 ; Nord, 1927; Staemmler, 1933; Pawlikowski, 1935). Generally speaking, the present results on the cytoplasmic structures are in essential agreement with those of earlier workers. The continuous transformation series of these structures may be regarded as relating to the secretory process of the medullary cells. The variations in the granulation and vacuolation in different cells appear to be dependant on the different phases of secretory activity. In this connection, classification of the medullary cells into two types, light and dark cells, has been described in the rat, based on cytological differences (Kameda, 1936; Adachi, 1944). From the above, however, it is likely, as suggested by Hirai (1933), Enjo (1947a) and others, that these two cell types merely represent the different functional phases, and that the medullary cells are probably of one type. Moreover, the chromaffin reaction presented by the medullary cells of the guinea pig varies greatly in intensity from cell to cell, as noted by Fuhrmann (1904). The medullary cells with the most intense reaction generally show little vocuolation, and assume a more or less angular form appearing elongated through compression. Such cells are probably the forms designated as dark cells, but they merely represent one stage of dynamic changes. In any case these findings may also be as testifying to the above view.

The cytoplasm of the medullary cells contains small, round or ovoid bodies staining intensely with eosin or iron hematoxylin (fig. 9). The bodies are somewhat variable in size, but many of them are about $1.5-3 \mu$ in diameter. Within a single cell, there is generally present a 
single body, but occasionally two or more.

The bodies develop in late embryonal life, and are of constant occurrence in postnatal life.

Such bodies have been described by many authors in various species including man (Scheel, 1908; Kolmer, 1912; Hirai, 1933; Enjo, 1947a). At present, however, there remains uncertainty regarding their significance. Such bodies sometimes seem to have been designated as Russel's bodies which probably occur pathologically rather than physiologically. On the contrary, Scheel (1908) regarded them as secretory granules; Hirai (1933), as a kind of secretory granules; and Enjo (1947a), as storage of adrenalin. According to the present observations, these bodies are present under physiological conditions, and histologically they look like colloid such as is seen in other glands. Hence, they may be called colloid bodies. However, there must be further study before a definite conclusion can be reached concerning the significance of the bodies.

\section{Conclusions}

1. The medullary anlage composed of the sympathogonia is found along the dorso-medial periphery of the cortical anlage in the $2 \mathrm{~cm}$ embryo. The migration of the sympathogonia continues until approximately the $4.5 \mathrm{~cm}$ stage. Most of these cells gradually become differentiated into pheochromoblasts, and some, into sympathoblasts. "The sympathogonia sometimes undergo degeneration simultaneously with multiplication. These cells are generally no longer found after the $9 \mathrm{~cm}$ stage.

2. The pheochromoblasts differentiate into the pheochromocytes after passing through the immature and mature stages. The immature and mature pheochromoblasts generally disappear after the 20th day of age, but the latter may rarely persist even in advanced life. These cells show intense mitotic proliferation.

3. The pheochromocytes make their first appearance in the embryo of $6 \mathrm{~cm}$, and then the chromaffin reaction gradually become marked with increase in number of these cells. At about 10 days of age these cells constitute nearly all the medullary elements.

4. The sympathoblasts first appear in the $3-3.3 \mathrm{~cm}$ embryos. The transformation of these cells into tne ganglion cells begins at the $7 \mathrm{~cm}$ stage, and is completed at the time of birth. The sympathoblasts show few mitotic divisions, and some of them undergo degenerative changes. 
5. The vascularity of the medulla reaches almost a definite condition in late embroynal life. Concomitant with the development of vascularization, the stroma becomes gradually developed in late embryonal and early postnatal life, until at about 8-10 days of age the medulla shows an architecture similar to the definite medulla.

6. The medullary cells, pheochromocytes, are generally arranged in irregular clumps or cords. These cell groups are surrounded by a small amount of connective tissue containing abundant elastic and reticular fibers, and they are in contact with the sinusoidal or capillary vessels.

7. The medullary cells vary considerably in shape from irregular polygonal to somewhat columnar forms, but the shape variations are relative and transitional in degree.

8. The nuclei of the medullary cells are round or oval, vesicular and generally occupy a more or less eccentric position. They are fairly uniform in size, but there are rarely found large nuclei whose significance is as yet little known. The nuclei sometimes contain an intranuclear inclusion which appears as a prominent sphere.

9. The cytoplasm of the medullary cells possesses fine granules and vacuoles of varying sizes. A continuous transformation series from the granules into the vacuoles may be regarded as related to the secretory process of the medullary cells. The cytoplasm often contains small, round or ovoid bodies which probably are the colloid substances.

I wish to express my hearty thanks to Prof. Ch. Togari for his kind encouragement and advice during the course of this study. I am also indebted to Mr. Sh. Kido for the drawings in this paper.

\section{Literature Cited}

Adachi, N. 1944 On the medullary cells (Japanese). Kaibo. Z., vol. 22, pp. 445-451.

Bennett, H.S., and Kilham, L. 1910 The blood vessels of the adrenal gland of the adult cat. Anat. Rec., vol. 77, pp. 447-471.

Bessho, M. 1927 a A histological and histogenetic study of the adrenal gland in the mouse (Japanese). AICHI IGAKUKAI ZASSHI, vol. 34, pp. 909-985.

$1927 \mathrm{~b}$ A histological and histogenetic study of the adrenal gland in the rat (Japanese). Ibid., vol. 34, pp. 1619-1645.

Bloch, R. 1921 Einiges zur postfötalen Entwicklung der Nebenniere des Meerschweinchens. Virchow's Arch., Bd. 232, S. 232-280.

Clara, M. 1937 Über die physiologische Regeneration der Nebennierenmarkzellen beim Menschen. Z. Zellforsch., Bd. 25, S. 221-235.

Coupland, R.E. 1952 The prenatal development of the abdominal para-aortic bodies in man. J. Anat., vol. 86, pp. 357-372. 
Dewitzky, W. 1912 Beiträge zur Histologie der Nebennieren. Beitr. pathol. Anat., Bd. 52, S. 431-443.

Enjo, Ko 1947 a A cytological study of the adrenal gland of man II. Cytology of the medullary cells with special emphasis on the secretory process (Japanese). Kaibo. Z., vol. 23, pp. 41-42.

$1947 \mathrm{~b}$ A cytological study of the adrenal gland of man III. Nuclei of the medullary cells (Japanese). Ibid., vol. 23, pp. 43-44.

Fuhrmann, F. 1904 Der feinere Bau der Nebenniere des Meerschweinchens. Anat. Anz., Bd. 24, S. 606608 .

Harman, Mary ' $\mathrm{T}$., and Derbyshire, Russel C. 1932 The development of the supra. renal glands in the guinea-pig (Cavia Cobaya). Am. J. Anat., vol. 49. pp. 335-349.

Hett, J. 1925 Ein Beitrag zur Histogenese der menschlichen Nebenniere. Z. mikrosk. anat. Forsch., Bd. 3, S. 179-282.

Hirai, M. 1933 A cytological study of the adrenal medulla (Japanese). Japanese J. experim. Med., vol. 17; pp. 847-861.

Jackson, C. M. 1919 The postnatal development of the suprarenal gland-and the effects of inanition upon its growth and structure in the albino rat. Am. J. Anat., vol. 25, pp. 221-289.

Kahn, R. H. 1911 Zuckers'ich und Nebennieren. Pflüger's Arch., Bd. 140, S. 209-255. 1926 Über die zentrale Reizung der Nebennieren und der Paraganglien während der Insulinvergiftung. Ibid., Bd. 212, S. 54-63.

Kameda, J. 1936 A cytological study of the adrenal medulla (Japanese). Kaibo. Z., vol. 8, np. 1021-1043.

Keene, M.F. Lucas and Hewer, E.E. 1927 Observations on the development of the human suprarenal gland. J. Anat., vol. 61, pp. 302-324.

Kodama, K. 1933 A histological study of the stroma of the adrenal gland (Japanese). Kaibo. Z, vol. 6, pp. 160-168.

Kohno, S. 1925 Zur vergleichenden Histologie und Embryologie der Nebenniere der Säuger und der Menschen. Z. Anat., Bd. 77, S. 419-480.

Kolmer, W. 1912 Beziehungen von Nebenniere und Geschlechtsfunktion. Pflünger's Arch., Bd. 144, S. 361-395.

1918 Zur vergleichenden Histologie, Zytologie und Entwicklungsgeschichte der Säugernebənniere. Arch. mikr. Anat., Bd. 91, S. 1-139.

Kudo, T., and Kakiyama, T. $1950 \mathrm{a}$ On the development of the suprarenal gland of mammalia. 1. Bat (Japanese). IGAKU TO SEIBUTSUGAKU. vol. 17, pp 23-25.

$1950 \mathrm{~b}$ On the development of the suprarenal gland of mammalia. 2. Rabbit (Japanese). Ibid., vol. 17, pp. 112-114.

$1950 \mathrm{c}$ On the development of the suprarenal gland of mammalia. 3. Mouse (Japanese). Ibid., vol. 17, pp. 247-249.

Lever, J.D. 1952 Observations on the adrenal blood vessels in the rat. J. Anat., vol. 86, pp. 459-467.

Nord, F. 1927 Über den Einflußes von einigen Aminosäuren auf das chromaffine Gewebe der Nebenniere des Kaninchens. Beitr. pathol. Anat., Bd. 78, S. 297-302.

Pawlikowski, T. 1935 Sur les vacuoles incrétoires dans les cellules adrénalinogènes de la zone médullaire des glandes surrénales du cobaye. C. r. Soc. Biol., tom. 120, pp. $469-473$.

Poll, H. 1906 Die vergleichende Entwicklungsgeschichte der Nebennierensysteme der Wirbeltiere. In Hertwig's Handbuch d. vergl. u. cxperim. Entw. d. Wirbeltiere, Bd. 3, T1. 1. Jena : Fischer. 
Scheel, O. 1908 Über Nebennieren. Sekretkörnchen-Ödem.Gewicht. Virchow's Arch., Bd. 192 , S. $494-513$.

Staemmler, M. 1933 Die Funktion des Nebennierenmarkes und ihr histologischer Ausdruck. Beitr. pathol. Anat., Bd. 91, S. 30-58.

Stoerk, O., and Haberer, H. 1908 Beitrag zur Morphulogie des Nebennierenmarkes. Arch. mikr. Anat., Bd. 72, S. 481-496.

Weymann, M.F. 1922 The beginning and development of function in the suprarenal medulla of pig embryos. Anat. Rec., vol. 24, pp. 2ऽ9-308.

Whitehead, R. H. 1903 The histogenesis of the adrenal in the pig. Am. J. Anat., vol. 2, pp. 349-360.

Wiesel, J. 1901 Über die Entwickelung der Nebenniere des Schweines besonders der Marksubstınz. Anat. Heft., Bd. 16, S. 115-150.

1902 Beiträge zur Anatomie und Entwickelung der menschlichen Nebenniere. Anat. Heft., Bd. 19, S. 481-521.

\section{Explanation of Figures}

Fig. 1 Drawn from a section of the adrenal of a $3.5 \mathrm{~cm}$ embryo. A group of sympathogonia in the cortical tissue.

(Zenker-formalin-acetic acid fixation; hematoxylin-eosin stain)

Fig. 2 Drawn from the same section as above. A group of pheochromoblasts of immature type.

Fig. 3 Drawn from a section of the adrenal of a $5 \mathrm{~cm}$ embryo. Degeneration (central and right) and mitosis (left) in a group of sympathogonia.

(Zenker-formalin-acetic acid fixation; hematoxylin-eosin stain)

Fig. 4 Drawn from a section of the same adrenal as above. A group of mature pheochro. mocytes. They assume an elongated form arranged with their long diameter perpendicular to the blood vessel.

Fig. 5 Drawn from a section of the same adrenal as above. A group of sympathoblasts showing the various stages of differentiation.

Fig. 6 Drawn from a section of the adrenal medulla of a 100 days old male. Intranuclear spheres of the medullary cells.

(Bouin fixation; hematoxylin-eosin stain)

Fig. 7 Drawn from a section of the adrenal medulla of a 214 days old female. A group of medullary cells assuming an elongated form with the long axis perpendicular to the blood vessel (above).

Note the fine granules and the vaculoles of varying sizes in the cytoplasm. In the center a part of a dark cell showing little vacuolation is seen.

(Ciaccio fixation; iron-hematoxylin stain)

Fig. 8 Drawn from the same section as above. A polygonal medullary cell.

Fig. 9 Drawn from a section of the adrenal medulla of a 350 days old male. Colloid body in medullary cell.

(Ciaccio fixation; hematoxylin-eosin stain) 


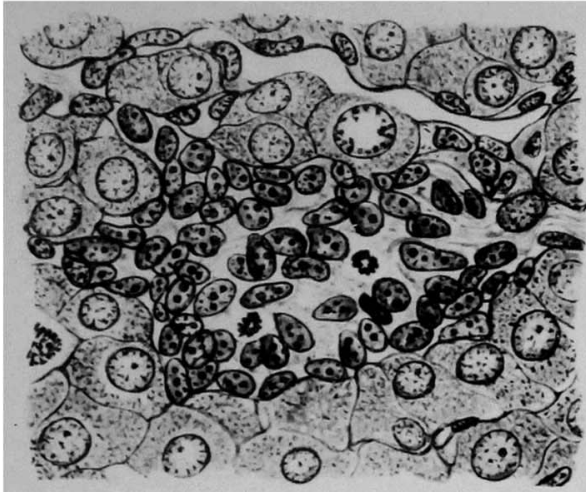

Fig. I

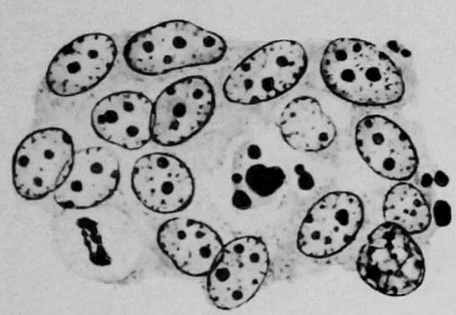

Fig. 3

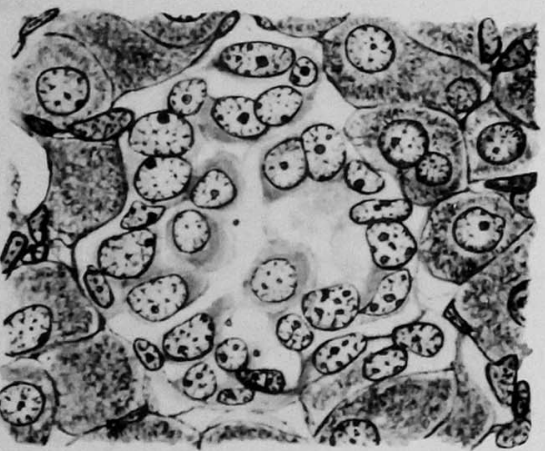

Fig. 5

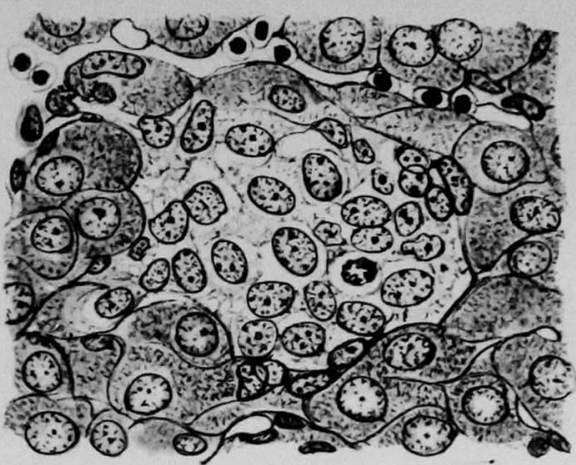

Fig. 2

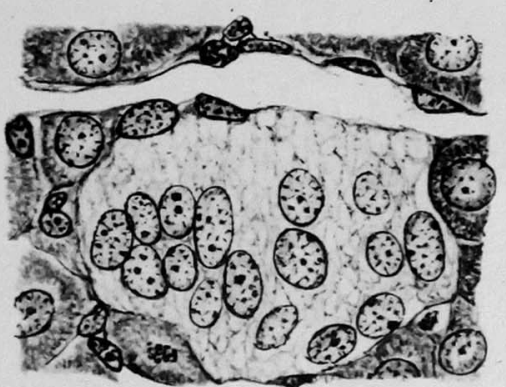

Fig. 4

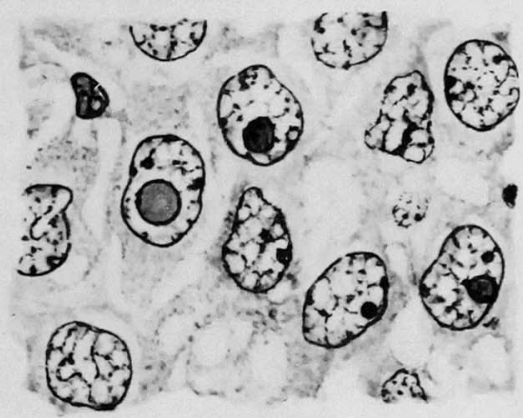

Fig. 6

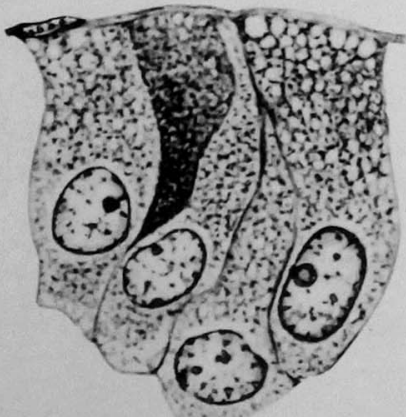

Fig. 7

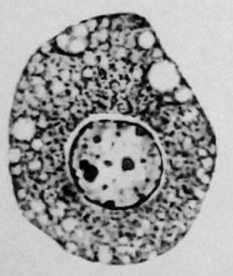

Fig. 8

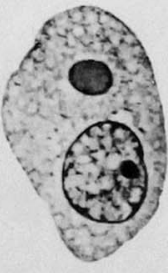

Fig. 9 